Article

\title{
The Justice Dimension of Sustainability: A Systematic and General Conceptual Framework
}

\section{Klara Helene Stumpf ${ }^{1,2, *}$, Stefan Baumgärtner ${ }^{1,3}$, Christian U. Becker ${ }^{4}$ and Stefanie Sievers-Glotzbach 1,5}

1 Sustainability Economics Group, Leuphana University of Lüneburg, Scharnhorststraße 1, D-21335 Lüneburg, Germany

2 Norbert Elias Center for Transformation Design and Research, Europa-University Flensburg, Auf dem Campus 1, D-24943 Flensburg, Germany

3 Department of Environment and Natural Resources, University of Freiburg, Tennenbacher Str. 4, Freiburg D-79106, Germany; E-Mail: stefan.baumgaertner@ere.uni-freiburg.de

4 College of Business, Colorado State University, 1271 Campus Delivery, Fort Collins, CO 80523-1271, USA; E-Mail: chris.becker@colostate.edu

5 Ecological Economics Group, Carl von Ossietzky University of Oldenburg, Postfach 2503, Oldenburg D-26111, Germany; E-Mail: stefanie.sievers-glotzbach@uni-oldenburg.de

* Author to whom correspondence should be addressed; E-Mail: klara.stumpf@uni-flensburg.de; Tel.: +49-461-805-2872.

Academic Editor: Marc A. Rosen

Received: 25 March 2015 / Accepted: 22 May 2015 / Published: 9 June 2015

\begin{abstract}
We discuss how the normative dimension of sustainability can be captured in terms of justice. We (i) identify the core characteristics of the concept of sustainability and discuss underlying ethical, ontological and epistemological assumptions; (ii) introduce a general conceptual structure of justice for the analysis and comparison of different conceptions of justice; and (iii) employ this conceptual structure to determine the specific characteristics and challenges of justice in the context of sustainability. We demonstrate that sustainability raises specific and partly new challenges of justice regarding the community of justice, the judicandum, the informational base, the principles, and the instruments of justice.
\end{abstract}

Keywords: conceptual structure of justice; epistemology; ontology; sustainability ethics; sustainability justice; sustainability science 


\section{Introduction}

Sustainability is a societal vision about how to act within coupled social and natural systems over the long term. The modern concept of sustainability, as it has evolved and gained global momentum since the 1980s, obviously has a normative dimension. This normative dimension is of key importance for sustainability policy and public debate, as well as for sustainability research [1,2]. In this paper, we discuss how this normative dimension can be interpreted in terms of justice. Justice concerns a fair balance of mutual claims and obligations within a community. Justice issues are at the centre of morality and ethics [3], and are particularly pressing in the sustainability context. While there are other-not mutually exclusive - perspectives such as responsibility [4-7], virtues, the good life, and ethics of care $[2,8]$, we consider justice to be a good candidate for the specification of the normative dimension of sustainability because justice is well suited to address concerns of limits, scarcities and conflicts. We ask: What are the characteristics and challenges of justice in the context of sustainability? What is an adequate approach to analyse them?

\subsection{Motivation and Aim}

Exploring the justice dimension of sustainability is important for several reasons. Debates in different sustainability policy fields increasingly put a strong focus on justice concerns, for example in international climate negotiations (see [9] for further examples). Those advocating fairness and equity in these arenas can benefit from good justification for these objectives, or, as Barry [10] (p. 63) puts it: "It is surely at least something to be able to assure those who spend their days trying to gain support for measures intended to improve the prospects of future generations that such measures do not represent optional benevolence on our part but are demanded by elementary considerations of justice".

The exploration of the justice dimension of sustainability is also worthwhile for more theoretical, and philosophical, reasons. Sustainability and justice are both contestable, and contested, concepts [11-15]. There is therefore a need to clarify their meanings and systematic relationships in order to develop a conceptual basis for further discussions of justice in the context of sustainability. This in turn may also contribute to avoid the misuse of the two concepts (and their relationship) as purely rhetoric devices in terms of a "legitimizing game" in politics [12] (pp. 242-243).

Contested concepts, such as sustainability and justice, generally have two levels of meaning [13]. The first level of meaning refers to the unitary, undisputed, but also vague general idea represented by the concept and is constituted by a number of core characteristics. We refer to this first level as the level of the general concept. The second level of meaning is "where the contest occurs: political argument over how the concept should be interpreted in practice" [13] (p. 25). At this second level of meaning, different ways in which the concept can be understood and specified, and therefore alternative conceptions of the concept, are discussed. We refer to this second level as the level of specific conceptions (for the concept-conception distinction, see also [16,17] and, in the sustainability context [18] (p. 788) and [19] (p. 402)).

Our analysis proceeds mainly at the level of general concepts. We ask what the core meanings and circumstances of the concept of sustainability imply for the specification of its normative dimension in terms of justice. That is, we outline requirements for sustainability-fitting justice conceptions (in short: 
"sustainability justice") and determine specific characteristics and challenges of justice in the context of sustainability.

While our focus is on the general concepts, we also refer to specific conceptions of justice and sustainability to illustrate particular points, and to back up and reinforce our analytical argumentation in a synthetic way.

Our aim is to map out the space of possible specifications of sustainability justice. We outline a set of characteristics and requirements for any sustainability-fitting justice conception, without suggesting one specific conception. While the relationship between justice and sustainability has been debated to some extent, a systematic analysis of the requirements for justice arising from the sustainability concept is lacking so far. In this paper, we address this research gap and provide a theoretical framework that can serve future debates about justice in the context of sustainability.

\subsection{Relation to the Literature}

This paper relates to a range of existing literature that discuss various conceptual and normative aspects of sustainability (e.g., [8,13,19-26]), as well as to contributions that elaborate more specifically on three justice dimensions of sustainability: intragenerational justice [27,28], intergenerational justice [10,29-37], inter- and intragenerational justice [38], and justice towards nature [39-43].

Most of these contributions either discuss proposals for specific conceptions of justice, or refer to only one or two specific dimensions of sustainability, e.g., intergenerational justice or justice towards nature. In contrast, we develop a meta-approach to sustainability justice (for further meta-approaches, see $[12,19,20,44])$, mapping out the theoretical framework and requirements for sustainability-fitting justice conceptions by considering all three relationships that matter for sustainability: the relationships among contemporaries, with future generations, and with nature. With this, our approach identifies the space within which existing and potential future conceptions of sustainability justice may be located. Our approach can thus help to compare and evaluate different conceptions of sustainability justice, and develop new ones.

\subsection{Outline of the Argument}

We argue (in Section 2) that the general concept of sustainability has certain core characteristics which are common to all conceptions of sustainability. However, the way these core characteristics are interpreted differs between different conceptions of sustainability. This is based at least partly on different underlying assumptions, as regards the understanding of the human being, nature and their relationships (ontological assumptions), as regards questions of knowledge, uncertainty and ignorance (epistemological assumptions), and as regards questions of moral status, values and norms (ethical assumptions). We therefore first address these types of underlying assumptions (Section 2.1) before we flesh out the core characteristics of sustainability and their conceptual variations between different conceptions of sustainability (Section 2.2).

We further show (in Section 3) that the general concept of justice can be captured by a formal conceptual structure of justice, comprising and relating the elements needed to comprehensively describe any conception of justice. These elements are the community of justice including claim holders and claim addressees, the claims of the claim holders and corresponding obligations of the claim 
addressees, the judicandum (that which is to be judged as just or unjust), the informational base of the justice judgment, the principles of justice, and — on a more practical level - the instruments of justice.

We then link (in Section 4) the concepts of sustainability and justice to discuss the justice dimension of sustainability. We argue that the core characteristics of sustainability imply certain specifications along the elements of the conceptual structure of justice. We demonstrate that the sustainability concept entails specific and partly new challenges of justice in regard to the community of justice, the claims and obligations, the judicandum, the informational base, the principles and the instruments of justice.

Finally (in Section 5), we sum up the requirements for any sustainability-fitting conception of justice and show that sustainability justice requires substantial modifications of established theories of justice in order to adequately analyse issues of justice in the context of sustainability. We end by drawing some conclusions for the conceptual debate, as well as for sustainability policy and research.

\section{Sustainability}

Sustainability has become a prominent concept in societal and political discourses around the world and serves as a major guideline for political actions and future societal development. There is an enormous breadth and variety of different conceptions of sustainability in the political, practical and academic arenas (for meta-studies see e.g., [2,11-13,19,20,44-52]). Sustainability can be characterized as a "thick" normative concept [53-55]: it carries both normative and descriptive content. Sustainability is an integrative concept in various ways, linking different issues such as environmental deterioration and human poverty, and looking to resolve them simultaneously and, at best, in a mutually reinforcing way [20,56]. It is also a contested concept [11,13-15], characterized by a set of core characteristics, along with different interpretations of these core characteristics in different conceptions. These conceptual variations depend, at least partly, on different underlying assumptions.

\subsection{Underlying Ontological, Epistemological and Ethical Assumptions}

Different sustainability conceptions build on different, explicit or implicit, assumptions about the world ("world views" or "basic constructions of the world"; $c f$. [57] (Section 4)). This includes especially ontological, epistemological and ethical assumptions.

The first set of assumptions is about the human being, about its fundamental constitution and motivational structure, about the relationship between the individual and society, about nature and about the human-nature relationship. We call these ontological assumptions, as they are about the entities that exist in the world and their relationships. For example, the human being may be conceptualized as a relational being with a "fundamental-ontological reliance on nonhuman collectives and processes" [58] (p. 390) (see also [50]). This contrasts with a more narrow understanding of the human being that works on the assumptions of the "homo oeconomicus" model and considers the relation between humans and nonhumans in terms of instrumentality only [50,58]. Nature may be seen as "the other" and contrasted with the essence of human being, or humans may be seen as part of nature $[59,60]$. There are different assumptions about the vulnerability of nature to human influence. In the Brundtland report, nature is characterized as "bountiful, but [...] also fragile and finely balanced" [61] (Chapter $1 \S 23$ ). According to Jonas [62,63], human power and impact on the environment are greater than ever. There are also differing accounts of what motivates individuals and 
which logic individuals follow (e.g., [64,65]). Understandings of the relationship between the individual and society may vary from seeing society as a loose framework for individual opportunities and values, to an encompassing, identity-defining structure (e.g., [66]).

The second set of assumptions answers to questions such as: What can one know? What cannot be known? How can one learn? Which forms of knowledge are there? Where does one encounter irreducible ignorance? What are the criteria for accepting a statement as true, valid, appropriate or coherent? We call these epistemological assumptions, as they are about knowledge and learning. Different epistemological positions differ in the criteria they define for knowledge (justified true beliefs) about propositions, such as justification by evidence or justification by reliable cognitive processes [67]. Different schools in philosophy of science, such as (critical) realism or (strong or weak) social constructivism, take different stances on the existence of an objective reality independent of human observation, and on the possibility to observe and assess this reality (see e.g., [68], for particular positions in the sustainability context see [66,69-71]). The question "What can we know?" is the basis for the questions "What can we control? What possibilities of action do we have? What can we do?" [72]. Thus, assumptions about one's possibilities of knowing also have implications for one's possibilities of acting. This obviously becomes relevant in the sustainability context when it comes to questions of how to act in a sustainable manner (see, e.g., [2]).

Assumptions about risk, uncertainty and ignorance are an important subset of epistemological assumptions. While the terms "Knightian risk" and "uncertainty" refer to the assumption of a fully specified set of outcomes (with given objective probabilities in case of risk, without probabilities in case of uncertainty), the term "ignorance" refers to the assumed inability even to specify all possible outcomes [72]. The standard assumption in modern science is that ignorance is reducible to risk (so that one can make statements about the possible states of the world and their probabilities). Faber et al. [72] point out, however, that there are instances of irreducible ignorance, due to reasons that lie in characteristics of the subject matter ("phenomenological ignorance", e.g., about "chaotic" systems) or in humans' way of conceiving the phenomena, such as ambiguities in language, the impossibility to determine the truth of axioms, and incompleteness of logical systems ("epistemological ignorance"). Proponents of post-normal science (e.g., $[69,70]$ ) advocate for a criterion of quality (rather than truth) of knowledge, defined as "the degree to which the recommended policy choices are robust against [...] underlying uncertainties" [69] (p. 202). Epistemological assumptions also concern the knowability and origin of values, norms and interests, especially related to the natural world [59,73-75]. Ontological and epistemological issues are also connected to empirical observation by influencing what one observes, and how one observes it. Empirical observations in turn contribute to one's understanding of the world and might also change some of the ontological and epistemological assumptions in a constant process of narrowing and refining ( $c f$. [71]). In the sustainability context empirical observation can become rather complex, where indirect effects and relationships are concerned. Still, sustainability ethics is crucially dependent on scientific, empirical knowledge about the world.

The third set of assumptions includes axiological views on which entities have value (and based on which criteria) (e.g., [58]), prescriptive statements about "the kind of world we want to live in and want to leave as a legacy" [20] (p. 1645), and statements about which norms should be followed and which "grounds of justice" [76] should be taken into account. We call these ethical assumptions, as 
they are about basic evaluative and prescriptive statements. Different grounds of justice and different criteria for moral status will be discussed throughout the paper.

\subsection{Core Characteristics and Conceptual Variations of Sustainability}

As a contested concept, sustainability is characterized by a number of core characteristics at the level of the general concept, which are interpreted in different ways by different specific conceptions of sustainability. Following and extending [2], we identify a number of core characteristics and their interpretation, i.e., their conceptual variations, from an analysis of the term "sustainability" and the related literature which reflects the prominent debate on the global challenge of sustainability since the 1980s (for other approaches to the core content of sustainability, see [12,13,18,46], and [11] for a critique of misuses of the term). By the term "core characteristics", we refer to meanings of the term "sustainability", as well as to "circumstances" of sustainability, i.e., the contexts in which sustainability becomes relevant.

Continuance. Literally, sustainability means the ability to sustain, that is, to maintain or continue, something $[2,11,77]$. Different conceptions of sustainability differ with regard to what exactly is to be continued [47]. This can be certain systems (e.g., ecosystems, societal systems), certain entities (e.g., species, capital, organisations), certain processes (e.g., evolutionary processes), or certain measures evaluating or following from these (e.g., wealth, well-being) [2] (p. 9). Implicitly or explicitly (depending on the sustainability conception), all of these are to be continued because they are or lead to something of value. Therefore, continuance as a core characteristic of the sustainability concept is not to be seen in isolation, but connected to certain ethical criteria (see the next paragraph on "normative orientation"). So-called "weak" and "strong" conceptions of sustainability differ with regard to the types of capital that are to be continued (e.g., [78]). Weak sustainability requires that the total capital stock be held (at least) constant. It builds on the assumption that "natural capital" is just one of many different capital stocks that can yield services for humans, and is substitutable against other capital stocks (see $[48,49,78]$ for examples). Strong sustainability requires that "natural capital" be maintained separately, assuming that nature is not (or, for ethical reasons, should not be) substitutable against any type of capital (see also [51,52]).

Continuance can refer to an active process of maintaining the systems, processes, entities or measures in question, or to the sustaining of conditions under which they can sustain themselves and flourish on their own. For being able to maintain such systems, processes, entities, or measures (or their conditions of self-maintenance), it is necessary to sufficiently understand their functioning. This has become the main field of contribution of scientific research to the sustainability debates [2].

Normative orientation. Sustainability has a normative meaning. "Sustainability is widely understood to be something positive; something for which one should strive" [2] (p. 11) (see also [20] (p. 1644) and [79] (p. 20)). Crucial political documents on sustainability [80-82] clearly embody the normative meaning and take sustainability as a guiding principle. However, one needs to further clarify and construe this normative meaning. What kind of norm is sustainability? A clarification of the normative meaning of sustainability cannot come from sciences and cannot be merely grounded in the continuance aspect $[2,20,56,83]$. Continuance is not a norm in itself. Sustainability does not mean that one should maintain any system, process, entity or measure [2] (pp. 17-18) (see also [11]). One needs to have a qualifier, further ethical criteria, to decide what systems, entities, processes etc. one should 
continue. One needs to give good reasons why sustainability should be pursued, i.e., what it is that is valuable to sustain and why this compells one to act accordingly. In Section 4 of this paper, we will substantiate this normative meaning of sustainability in terms of justice.

Encompassing scope. Sustainability seeks to address environmental and developmental issues of considerable scope - both in space and in time. The global scale is probably a common feature of all sustainability conceptions [20]. Many community or "Local Agenda 21" groups operate under the imperative "act locally, think globally" [84], pointing to the fact that while they act locally, their quest for sustainability ultimately aims at global improvements. However, different conceptions of sustainability differ in the time horizons they consider - from 25 years (as a minimum time horizon of one generation into the future)to an unspecified "now and in the future" (as in the Brundtland report) to several generations ("at least 100 years" [49]) to forever (for overviews see [79,85]). As an integrative concept, sustainability seeks to address the encompassing spatial and temporal scope at the same time.

Threefold relationality. The modern concept of sustainability, as it has evolved and gained global momentum since the 1980s, is essentially about fundamental relationships of the human being. The individual human being is conceptualized as being related to contemporary humans, future humans, and non-human nature [2] (p. 12). This becomes obvious e.g., from the prominent definition given by the Brundtland Report, where sustainable development is defined as "development that meets the needs of the present without compromising the ability of future generations to meet their own needs" [61] (Chapter 2 §) (see also [80] and [86] (Annex II, pp. 154-162)). Sustainability, in this statement, is about the relationship between contemporaries and about the intertemporal relationship between generations. Sustainability also refers to the relationship between humans and nature: "In its broadest sense, the strategy for sustainable development aims to promote harmony among human beings and between humanity and nature" [61] (Chapter 2 § 81) (see also [86] (Annex II, pp. 154-155)). Thus, the term sustainability refers to an integrative view of three fundamental relationships of the human being: its relation to other contemporaries, other generations, and nature. Following [2] (Chapter 3), we call these relationships, in short, sustainability relations.

Different conceptions of sustainability differ in the way they interpret these relationships (e.g., [20]). Some focus more on intergenerational relationships (e.g., [26,49]), some more on global intragenerational relationships (e.g., [87]). In particular, while nature always plays some role for sustainability, this role is interpreted in different ways: Nature may be considered with regard to its instrumental function within intra- or intergenerational relationships, for instance as a life-support system (e.g., [61,88]) or a resource (e.g., [48]). On the other hand, the human-nature relationship may also be recognized as crucial by itself, assigning a moral status of its own to nature, or to specific natural entities, such as other living species on Earth with which humans share the environment $[20,43,61,89]$. For example, while conceptions of weak sustainability quite clearly are based on an instrumental interpretation of nature as natural capital, the non-substitutability of nature advocated by conceptions of strong sustainability may be grounded in the conviction that nature plays an irreplaceable (instrumental or eudemonistic) role for human well-being $[78,88]$ or it may be grounded in an ethical position that assumes moral claims of (entities in) nature (see e.g., [50,52,59,90], see [12] (pp. 40-41) for a critique of using the terminology of "natural capital" in the context of obligations to nature).

Nature may also be seen as a creative potential that inspires human creativity (Biomimicry or Bionics [91]), a model for human technological and economic processes (Industrial Ecology [92,93]), 
a fundamental condition and limitation of human activity (Ecological Economics [94]), a partner in co-evolutionary development [66], and a source of meaning and fulfilment for humans [2,59].

The way the relationship to nature is interpreted clearly has implications for whether actions within this relationship can be seen as an issue of justice. Anthropocentric conceptions of sustainability, where nature plays a merely instrumental role, for example, may imply no justice obligations towards nature. On the other hand, sustainability conceptions which regard the relationship to nature as crucial by itself can be spelled out in terms of justice towards nature. In this paper, taking a broad and inclusive approach, we discuss both possibilities (see Section 4.1.1 on "claim holders").

Some sustainability conceptions [2,59] strongly emphasize the relationality of the human being, as fundamentally related to other contemporaries, future generations, and nature. This implies putting the dominating modern (western) ideal of the human being as an autonomous and independent individual [95] into question [2] (similarly, [19] (p. 405)). Other sustainability conceptions, while acknowledging that future generations and nature play some role for sustainability, interpret these relationships in a weaker sense and still see the individual as primarily autonomous (for examples, see [78]). However interpreted, the sustainability concept implies a minimal ontological commitment to the existence of a relationship between current and future generations of humans and between humans and nature, which acquires some moral significance and raises normative and evaluative questions of how to act within them. Continuance of systems, processes, and entities then is just a means, a function, in regard to the normative obligations concerning the sustainability relations. The ability to continue certain — not all-systems, processes, or entities is crucial for the development of these relations.

Relational asymmetry. The relationships between contemporaries, between humans of the current and of future generations, and between humans and nature are highly asymmetric: Current humans have extended power and impact on the environment and on future humans and substantially determine their living conditions, but not vice versa (see e.g., $[62,63,78,96,97]$ ). Even within the current generation certain regions or societal groups have significantly more power and abilities to act than others, which plays an important role in the causation of the environmental crisis [73]. The relationship between humans and nature differs substantially from the relationship between human beings [2]. Different sustainability conceptions differ in the extent to which they take account of asymmetries in the sustainability relations. For example, the degree of irreversibility (i.e., an asymmetry in the relationship between current and future generations) built into models of standard resource economics is often weaker than in thermodynamic models of ecological economics [98].

Systemic mediation. Most of the relationships relevant in the sustainability context are relationships that are governed by systems of mediation. For instance, most global relationships today are not set up and realized deliberately by individuals, but are set up and governed by economic, scientific, and technological systems [2] (Chapter 7) [99]. Such systems are characterized by certain institutionalizations and by fundamental patterns of thought and action [2] (pp. 41-43). By everyday consumption and the market system, for instance, one is related to a huge number of people around the world involved in the production and distribution of the consumption goods or affected indirectly by various externalities [2]. At the same time, economic processes substantially affect the environment, which then has a crucial impact on other current and future humans and natural beings (see e.g., [59]). Looking only at an isolated action without considering mediating systems, one thus misses many indirect impacts. 
Sustainability conceptions should integrate these mediated impacts. However, few conceptions of sustainability seem to fully integrate systemic mediation.

Limits. The idea of limits is a key characteristic in practically all conceptions of sustainability [11,20,48,49,83,88] and [79] (p. 20). The concern about limitedness is also apparent in many empirical assessments of the condition of the world's biophysical and ecological systems [100-102] and of the "planetary boundaries" within which humanity can operate safely [103].

Different conceptions of sustainability differ in the exact definition and characterization of these limits. Limits are characterized in terms of technological and institutional restrictions and the limited ability of the biosphere to absorb the effects of human activities [61] (Chapter $2 \S 1$ ), tipping points of certain systems [78,103], limited or non-substitutability [78], absolute scarcity [104], ultimate limits of certain essential functions of the life support systems of the planet [20,79], thermodynamic restrictions [105-111] and limits in our ability to understand natural processes [49]. Different limits may hold for different resources or types of natural capital [78] (Chapter 4), also depending on technology and social organization [20]. "Nested" models of sustainability (where the economy or society is represented as a subset of the ecological system of the Earth) put more emphasis on ultimate limits of the Earth than, e.g., models representing the concern for sustainability as a concern for three or more "pillars" of equal standing, such as the economic, social and environmental [20]. Policy approaches such as the safe minimum standard [112,113] explicitly take account of limits and thresholds, while emphasizing (epistemological) doubt about how precisely one can know the location of such thresholds, and the precaution one should therefore take.

Uncertainty. Especially with regard to the environment and the future, uncertainty in different forms (cf. Section 2.1) plays an important role for sustainability [11,78]. These uncertainties concern, for example, our knowledge about how natural systems react to human intervention and about the potential development of societal and economic systems (see e.g., [20,49]). Some argue that the amount of ignorance, at least partly, depends on the design of the institutions and systems that govern our relationship with nature and future persons [2] (pp. 41-63). Furthermore, there is also considerable uncertainty about the values and norms of future generations, as well as about values in nature (e.g., [47,72,73,114]).

Different sustainability conceptions differ in the exact conceptualization of these uncertainties and build on different epistemological requirements. For example, conceptions of sustainability as constant or non-decreasing welfare or capital over time are difficult to substantiate empirically due to data deficiencies [49]. In contrast, approaches of "education for sustainable development" [115,116] emphasize continual learning and competencies for adaption to new challenges. Approaches such as the "precautionary principle" explicitly emphasize that it is necessary to respect uncertainty and avoid risks [20,117].

Summing up, the contested general concept of sustainability is subject to substantial conceptual variations in the different specific conceptions of sustainability that have been proposed. Nevertheless, a number of core characteristics can be identified (Box 1). These build on some minimum ontological assumptions, such as the existence of at least weak mediated relations between contemporary humans globally, at least a weak relation of contemporary humans to future humans and nature, the existence of at least some limits in the biophysical environment, and (at least to some extent) the ability of humans to influence nature and human dependence on nature. Epistemologically, sustainability presupposes the 
ability to recognize at least some aspects of the biophysical environment as an external reality, albeit subject to substantial uncertainties. To arrive at normative conclusions, additionally certain ethical assumptions (basic evaluative and prescriptive statements) are needed.

Box 1. Core characteristics of the sustainability concept.

\begin{tabular}{ll}
\hline - & Continuance \\
- & Normative orientation \\
- & Encompassing scope \\
- & Threefold relationality \\
- & Systemic mediation \\
- & Limits \\
\hline
\end{tabular}

\section{Justice}

As an ethical concept, justice belongs to the realm of judgments about right and wrong, good and bad. A main distinctive characteristic of justice is that it is a specific relational ethical concept. Justice considers actions, actors, institutions or states of affairs with regard to their impact on others and their entitlements (goods, rights, desert). Justice concerns that part of morality which is owed to others. It essentially (in its core meaning) bears on the owed, demandable claims (or rights) and the corresponding obligations within a community of justice, from the standpoint of impartiality and equal consideration (e.g., [118]). Like sustainability, justice is a contested concept ( $c f$. Section 1) and gives rise to different specific conceptions which depend, at least partly, on underlying assumptions about the world.

Particularly, different conceptions of justice define different claims, claim holders etc., depending on the specific grounds of justice on which they build [76]. Grounds of justice are the ethical reasons why claims of justice are legitimate for a certain group of claim holders (and why certain claim addressees have a corresponding obligation to fulfil the claims). Grounds of justice may be relational, referring to a shared practice such as sharing a state or taking part in the same global trading system, or they may refer to nonrelational features such as humanity, rationality or sentience.

Considering the characteristics of the general concept of justice, one can define a basic "conceptual structure" of its elements, which allows us to analyse and compare different conceptions of justice and to explore new definitions of justice in an analytical way [119]. The elements are the following (Box 2):

Box 2. Conceptual structure of justice.

- Community of justice

○ Claim holders

- Claim addressees

- Claims (and corresponding obligations)

- Judicandum

- Process/outcome perspective

- Informational base

- Principles of justice

- Instruments of justice 
Community of justice. Who is included into the justice consideration? This question refers to the delineation of the community of justice [12] and to the ascription of claims (or rights) and obligations to its members. The community of justice may include humans (in anthropocentric conceptions of justice), but may also include non-human entities or communities (in physio-, bio-, ecocentric or holistic conceptions of justice) (see $[119,120]$ ). Within the community of justice, we distinguish between two potential roles of its members: that of a claim holder (holding particular claims) and that of a claim addressee (bearing responsibility for the fulfilment of claims). The community of justice is constituted of all claim holders and all claim addressees, where any one member can hold both or only one of the roles. The status of a claim holder may be grounded in different grounds of justice [76] (for examples see [119]). Moral responsibility as a claim addressee can only be attributed to a person as far as the person is free to act voluntarily and intentionally, has sufficient knowledge and (for positive claims) sufficient power to potentially satisfy the claim [6] and [121] (Chapter 11). A claim addressee may also be a collective actor [119]. There may also be second-level claim addressees, such as the judicial system (see also [119]).

Claims. What are the legitimate claims that are held by the claim holders? The notion of a claim is central to the concept of justice [90] (p. 47). A claim is a right or desert to which the claim holder is fundamentally and legitimately entitled. It is ascribed to a member of the community of justice based on an accepted ground of justice or ethical foundation (see [119] for examples). Claims can be positive, i.e., defining an entitlement to a certain good (understood in a wide sense), or negative, i.e., demanding freedom from harm. Claims give rise to corresponding obligations for the claim addressees in the community of justice. Which claim addressee in particular is responsible for the satisfaction of a particular claim, or whether the obligation falls on the collective of all claim addressees, may be determined according to different considerations, inter alia in relation to the ground of justice that the claim is based on (see Section 4 for specific grounds of justice discussed in the sustainability context and [119] for a general discussion of grounds of justice and considerations to determine obligations).

Judicandum. What is the judicandum, i.e., who or what is judged to be just or unjust? There are several categories of judicanda [122] (p. 863): (i) individual or collective actors; (ii) actors' actions or omissions; (iii) social rules, i.e., laws, institutions, conventions; (iv) states of affairs or events. A judicandum may be considered in terms of outcome, or in terms of process (consequentialist vs. procedural justice sensu [12] (p. 70). As a normative statement, it only makes sense to speak of such entities as judicanda that can be, either directly or indirectly, changed or impacted by a claim addressee (see [119]).

Informational base. What is the evaluative space or informational base for the justice judgment? As Sen [123] pointed out in his lecture on "Equality of What?", it is an important dimension of moral judgments whether they are made on the basis of information about, e.g., utility, primary goods, or capabilities (see also [122] (p. 868)). In different domains of justice, different informational bases are important (see [119]).

Principles. What are the appropriate principles of justice? Principles of justice may apply to the way claims of justice are considered (and correspondingly, how the informational base is applied), or they may apply to the way obligations of justice are construed. Mainly four principles are discussed: equality, proportionality, priority, and sufficiency (for the first three see [124] (p. 8), for sufficiency see [125] (p. 22) and [126] (p. 237)). The principle of equality can be understood in a formal sense-equal 
consideration as a claim holder — or in a substantive sense, e.g., equal shares in distribution. All principles require further specification (e.g., proportionality to need or merit) (see [119]).

Instruments of justice. On a more practical level, one may ask: Which instruments shall be employed to satisfy the claims of the claim holders [127]? The term "instruments" may refer to a range of different options, such as objects to be distributed (e.g., [12] (pp. 73-76)), institutional reform (e.g., [128]), or a change in attitudes (referring, e.g., to virtue ethics [129])—whatever seems fit to achieve the satisfaction of the claims defined by the specific conception of justice (see [119] for examples).

\section{The Justice Dimension of Sustainability}

Where conflicting claims exist in any of the three sustainability relations relations (i.e., the relations among contemporaries, with future generations, and with nature), this raises the question of what would be just in this relationship. Moreover, potential conflicts and trade-offs between different relationships (e.g., between intra- and intergenerational relationships) also lead to questions of justice (see e.g., [83,130]). Sustainability actually requires an integrated conception of sustainability justice with regard to all three sustainability relations. What would be just with regard to the threefold relatedness of human existence?

In this Section, we analyse how one needs to specify the elements of the conceptual structure of justice ( $c f$. Section 3) in order to substantiate the justice dimension of sustainability and therefore to arrive at requirements for any sustainability-fitting justice conception. We discuss each structural element in regard to the core characteristics of sustainability ( $c f$. Section 2 ), in order to determine the specific characteristics and challenges of justice in the context of sustainability. We take into account different grounds of justice.

\subsection{Community of Justice: Claim Holders and Claim Addressees}

The specification of the community of justice requires the specification of the (potentially overlapping) groups of claim holders and claim addressees.

\subsubsection{Claim Holders}

As sustainability is about continuance into the future, covers a wide scope in space and time, and builds on a threefold relationality of the human being with contemporaries, future generations, and nature (Section 2.2), the domain of application for sustainability justice is rather large and gives rise to many potential candidates for claim holder status. The threefold relationality implied in the sustainability concept (Section 2.2) raises the question of how to act justly within these relationships, and therefore which claims (and obligations) arise for which claim holders (and claim addressees) within these relations. The threefold relationality suggests a substantial extension of the group of claim holders to all members of the current generation and some or all members of future generations (see also $[19,131])$, and potentially non-human entities in nature as well.

Which of these candidates for claim holder status are then actually seen as claim holders, depends on the way the normative orientation of sustainability (Section 2.2) is spelled out, that is, how the criteria for assigning moral status, or more specifically, legitimate claims of justice, are defined. That is, it 
depends on the grounds of justice (Section 3) to be applied. Many of the grounds of justice that can legitimize claims of current humans apply to future humans, too (e.g., the status of personhood, human dignity and rationality, and so on). Non-anthropocentric conceptions of justice give various reasons for the inclusion of natural entities or communities into the community of justice [120]. But if nature or natural entities are seen merely as systems of mediation (as in certain anthropocentric conceptions, $c f$. Section 2.2) and not as morally significant in themselves, they cannot be defined as claim holders, and the relationship to nature therefore may not be seen as an issue of justice.

The definition of claim holders is further complicated by the asymmetry of the sustainability relations (Section 2.2), especially with regard to the future. The existence, number and identity of future persons depend, at least partly, on actions of the current generation. This has led to the formulation of the so called non-identity problem [32]: if a future person owes her existence to an action in the past, she cannot be said to be harmed by that action. This, however, depends on a specific notion of harm which compares the well-being (or other relevant metric) of the person to her well-being had the action not occurred. Using a threshold conception of harm, according to which "an action harms a person only if as a consequence of that action the (then existing) person falls below a normatively defined threshold" [96] (p. 16) allows avoiding the non-identity problem. Such a notion of harm assesses whether the affected person is "worse off than they should be" [96] (p. 20, emphasis added) as a result of the action, rather than assessing whether they would be better off had the action not occurred. Such a threshold could be defined in terms of different grounds of justice that are independent of the particular identity of the claim holder, such as the status of personhood (see e.g., [132]) or common humanity (see e.g., [96]).

As a distinct challenge to intergenerational justice, which is not concerned with this contingency of the future on current decisions, some philosophers have doubted the principal possibility of future people having rights or legitimate claims now, as they do not exist now [133]. This may be termed the non-existence problem [131]. However, one can safely assume that there will be at least some actual (as opposed to merely potential) persons in the future, that they will have some rights or legitimate claims (determined by whatever ground of justice is taken to apply, such as the interests or the good of these persons), and that present actions can affect whatever is protected by the right or claim. Thus, one can today violate future rights or claims of future persons $[75,96]$.

\subsubsection{Claim Addressees}

The group of claim addressees can logically only be constituted by such actors who fulfil the preconditions of bearing responsibility, i.e., they must be persons capable of acting out of free will and have sufficient knowledge and (for positive claims) power to potentially satisfy the relevant claims (see Section 3). Here, the importance of the worldview (cf. Section 2.1) on the specification of requirements for sustainability justice shows. What comes to be seen as a matter of concern giving rise to claims and obligations of justice depends on what is (ontologically and empirically) seen as changeable by claim addressees at all (see also [134] (p. 815)). Therefore claim addressees can belong to the current generation and potentially future generations (of humans), but not to non-human natures. This is connected to the asymmetry within the sustainability relations (Section 2.2), especially with regard to the power to impact others in a substantial way. Moreover, because responsibility in the 
moral sense can only be borne by actors with the characteristics of a person (see Section 3 and [119]), only such (individual or collective) actors can be conceptualized as a claim addressee, but not any diffuse entity or collective. For example, strictly speaking a diffuse collective such as "the consumers", "the current generation", or "the economy" cannot be properly defined as a claim addressee. However, individual members of such collectives can be claim addressees; and one can argue that they have a responsibility to work towards organizing themselves with others of the same diffuse collective to form a collective actor which can be a proper claim addressee. Also, well-constituted collectives that have, as a collective, all properties of a person, can be claim addressees. This includes in particular private or public corporations (e.g., associations, firms or states).

Different specific reasons (or grounds) for assigning claim addressee status to particular individual or collective actors have been discussed in the sustainability context. For example, one can argue that the current benefiters from past emissions have an obligation to help those currently harmed by these emissions on the grounds of a notion of intergenerational free-riding [135] (see also [136]). Other grounds for obligations which are frequently brought forward in the sustainability context are the ability to pay (e.g., [97,137,138]), and the polluter pays principle [135].

There might also be claims of future humans (or future natural entities) for which not the members of the current generation are proper addressees but members of another, intermediate generation in the future. This is connected to the asymmetry of the sustainability relations (Section 2.2), especially the "time-inconsistency problem of sustainability" [78] (p. 16) (see also [10]): members of the current generation cannot control whether members of intermediate generations adhere to what current actors see as required by sustainability. This limits current actors' responsibility (as one can only be held responsible for what one has the power to control), but also establishes some duties of members of the current generation with regard to members of intermediate and remote generations (see Section 4.2 for an elaboration).

In addition, due to uncertainty or ignorance (Sections 2.1 and 2.2), an actor might not know and might not be able to know the claims of future claim holders, or might not know that its current actions have implications for the claims of future claim holders. In the case of climate change, for instance, people today and in the future are impacted by the consequences of past emissions, which may violate their claims, e.g., to stay above a minimum threshold of well-being. However, it would be difficult to argue that members of past generations that caused much of the greenhouse gas emissions acted in an unjust manner towards those affected negatively today [135], i.e., did not fulfil their responsibility regarding future humans' legitimate claims, given that they could not know the effects of their actions, until the 1990 report of the Intergovernmental Panel on Climate Change [139], which is generally considered as the point in time from which on one could know, and should have known, about the dangers of climate change. Rather, parts of the current generation need to be considered as claim addressees on different grounds of justice, such as being a benefiter of past emissions or being able to satisfy the claims. One needs, therefore, a dynamic perspective on claim addressees, allowing for new claim addressees (and claims and obligations) to be defined in the future.

Because of the wide scope and the complex and interrelated nature of sustainability issues (e.g., due to systemic mediation, Section 2.2), claim addressees should not only be individuals, but also collective actors such as states or international organizations. The power of the collective actor should match the spatial and temporal scope of the problem for which the actor is claim addressee and should 
be of adequate extent to be able to address the complexity of the systems of mediation. If the actor has too little power, she cannot take responsibility for the problem; if the actor has too much power, this would be overregulation of the problem at hand. In the international respect, there are some approaches in this direction (e.g., the international court of justice), whereas in the intergenerational respect, not much has happened so far (but see Section 4.6 for some approaches). When setting up such collective actors, one should think about certain requirements. For one, in order to be a possible claim addressee, the collective actor needs to be capable of bearing responsibility (see Section 3). Also, the power of such collective actors should be transparent and controllable by those affected, for example by means of participation, as a matter of intragenerational justice.

Under non-ideal circumstances, a designated claim addressee may not actually fulfil her responsibility. For this case, a sustainability-fitting justice conception should have an answer. For example, one may construe a duty of others to "take up the slack" [140].

\subsection{Claims}

Having specified the community of justice according to the threefold relationality implied in the sustainability concept (Section 2.2) to include contemporary humans, humans of future generations and potentially non-human beings as claim holders (Section 4.1), one needs to define the claims of all these claim holders. For intragenerational claims one can build on the debates on global and international justice (for an overview see [141]) and environmental justice (e.g., [142]). In the following we will therefore mainly focus on how claims of members of future generations and of non-human beings could be defined in the sustainability context, taking into account the core characteristics of sustainability and different possible grounds of justice.

The continuance aspect, which is a core characteristic of the sustainability concept (Section 2.2), implies that there are intergenerational claims to sustain certain systems, processes, entities, etc. For example, this may refer to the stock of a renewable resource (such as a fish stock) which shall be maintained at a level that allows its continued use, or it may refer to a measure such as wealth, which shall be non-declining. Continuance as a literal meaning of sustainability alone cannot serve as a normative justification for these claims, however (see also Section 2.2). Rather, the claims of future claim holders need to be based on specific grounds of justice (some of which we will discuss in this Section, below). The continuance aspect then follows from these claims: Continuance of, e.g., a certain resource, may be an instrument to fulfil the claims of members of future generations. Besides the specific claims for the continuance of specific things (e.g., certain resources), one can argue for a general claim for the continuance of justice-enabling conditions. For example, Dower [38] argues that future humans have a claim towards current humans to sustain the "conditions in which justice can flourish" [38] (p. 399). This includes the stability of life-support systems [143], a certain quality of the natural environment today and in the future [37], but also the justice-enabling design of global structures today [99], which are passed on to future generations, as a claim content.

The recognition and proper dealing with the uncertainty and ignorance prevalent in the sustainability context (Section 2.2) also is a matter of justice. Members of future generations arguably have a claim towards members of previous generations not to increase risk and uncertainty and not to provoke surprising effects that harm future generations or burden them with new duties or claims that 
they will have to fulfil (see, e.g., [78] for some of the approaches of coping with risk, uncertainty, and ignorance and their associated difficulties). Arising from the asymmetric relationships (Section 2.2), the "time-inconsistency problem of sustainability" (see Section 4.1) also establishes some responsibilities regarding members of intermediate generations, for example education on sustainable development being the "right thing to do" [78], provision of the circumstances under which they can fulfil their respective duties [38], and an attitude of openness, flexibility and precaution to cope with instances of irreducible ignorance [72] (see Section 2.1). Uncertainty about the values and attitudes of future people (e.g., about their appreciation of nature) can also be used as an argument for more rather than less conservation of natural capital into the future ( $c f$. [26]).

As a further starting point into the inquiry about claims within the sustainability relations, one can look at one of the founding documents of the sustainability debate: The Brundtland report, which postulates "that every human being - those here and those who are to come- - has the right to life, and to a decent life" [61] (Chapter $1 \S 54$ ) and that conservation of nature is "part of our moral obligation to other living beings and future generations" [61] (Chapter $2 \S 55$ ). What is a decent life for humans, and how are obligations towards other living beings to be defined?

One way to define claims of contemporaries, future generations and natural beings (as far as they are sentient beings) could be in reference to Mill [3]. The basic claim would then be "individual security", meaning at least the right of sentient beings not to be hurt, but could also include rights to the basis of living or basic conditions of flourishing. This also links to some other current ethical discourses, e.g., to the utilitarian based discourses on animal rights [42], the discourse on human security [144,145], and on capabilities (e.g., [123,146], see also [147]). A related claim is the one for undiminished life opportunities, emphasizing the substantial freedom to choose (see e.g., [148]).

In reference to Aristotle's virtue ethics [129], another way of defining the claims of all beings involved could be as their "right" to be treated on the basis of sustainability virtues-i.e., attentiveness, receptiveness, care, and respect — as partners in the fundamental relational existence of sustainable persons [2]. Currently living and acting humans, in their role as claim addressee, then would have the respective duties to act virtuously toward all partners of the sustainability relations, i.e., other contemporaries, future people, and other natural entities. However, the sustainability virtues have different dimensions in themselves with regard to different partners, and the claims may also be considered to be different in relative importance (see e.g., [149]).

Regarding the sustainability relation between humans and nature, one can justify direct claims of nature or natural entities, such as e.g., not to be hurt and to be treated with respect (see above). Depending on the ground of justice, further claims of nature may be construed. Holland [134] (p. 821), for instance, points out that some authors ground moral standing on a capacity to be harmed which may be construed extremely broadly, extending e.g., to rivers as claimants to liberty (with reference to [150]). One may also argue that non-human natural entities have a "good" on which their claims should be based [43]. Additionally (whether or not a particular justification of claims of nature is accepted), any conception of sustainability justice will probably contain obligations towards other humans (including future generations) regarding nature (see e.g., [151]). This can be based on instrumental values of nature for humans in the narrow sense, but also on eudemonistic and relational values, aesthetic values, and so on (see e.g., [58,134]). 
As limits are an essential core characteristic of practically all sustainability conceptions (Section 2.2), the potential to satisfy claims within the sustainability relations arguably is limited, introducing potential conflicts between the claims of contemporaries, future humans, and potentially (entities in) nature. Where the three kinds of claims and corresponding obligations conflict, the claim addressees (Section 4.1) need to resolve these conflicts on the basis of ethical considerations in combination with feasibility concerns. It is thus a task for any sustainability-fitting conception of justice to give guidance on how to weigh these claims and how to handle the trade-offs. One possibility is to assign prima facie equal rank to the claims within the different relations, and then to look at the feasible combinations of attainment of these claims, i.e., to only look at trade-offs on the "production side" (cf. [152], for the distinction between the "value side" and the "production side", see also [153].). However, one might also wish to give normative reasons for decisions on trade-offs on the "value side", for example based on considerations of different moral standing (e.g., [149]), of different importance or urgency of the claims (e.g., [154]) or of different strength of the obligations [155] (see also Section 4.5).

\subsection{Judicandum}

Principally, all four categories of judicanda established in the literature (actors, actions, rules/institutions and states of affairs [122]) are relevant in the sustainability context. As a normative statement, it only makes sense to talk of such entities as judicanda that can be, either directly or indirectly, changed or impacted by a claim addressee. At the same time, the judicanda should correspond to the claims of all claim holders in the encompassing temporal and spatial scope implied by the sustainability concept (Section 2.2).

First, the individual actor may be considered as just or unjust. One specific conception of this could be spelled out in terms of virtue ethics. One may consider an enlightened self-identity as a fundamentally relational being (a temporally, socially and naturally contingent being inside the threefold relationality of sustainability, Section 2.2) as crucial for sustainability and define the excellence of such a being by a set of relational virtues, such as attentiveness, care or respect to other contemporaries, future beings, and natural entities [2]. Justice then would, in Aristotelian terms, mean the realization of these virtues in the right way in regard to others of the sustainability community. A person who is acting virtuously in this way would then be a just person. Further, one also needs to consider collective actors as judicanda, especially with regard to the scope and continuance aspects of sustainability (Section 2.2, see also Section 4.1).

Second, one also needs to consider a person's action and its consequences. The action of a person might be judged as unjust without necessarily judging the whole person as unjust. With regard to many sustainability issues, such as e.g., global climate change, one can identify actions and their impacts on others but may not be fully able to determine the individuals (causally) responsible for the action (i.e., uncertainty and ignorance play a role, see Section 2.2). One can nevertheless judge certain actions, e.g., increasing $\mathrm{CO}_{2}$ emissions, as unjust. The discussion of justice should be able to refer to actions even when a reference to individuals is not possible.

Third, institutions are important judicanda of sustainability justice, for example those institutions governing the distribution of resources (intragenerationally) such as trade rules, the institutions governing conservation of resources for the future (intergenerationally) such as conservation policies, and the 
rules concerning interactions between humans and nature such as regulations of production and consumption.

Fourth, many sustainability conceptions define a certain (future) state of affairs, or a development of such states over time, as "sustainable" or "just", such as a state of affairs in which certain critical stocks of natural capital are conserved. In the face of uncertainty (Section 2.2), the judicandum might not be a particular state of affairs in the future, but rather the reasonable expectations about possible future states of affairs. However, looking only at states of affairs in discrete points in time cannot tell us much about the transition between these states of affairs.

Among the most important judicanda of sustainability justice are the economic, technological and scientific systems ("systems of mediation", $c f$. Section 2.2) that cross through many nations and society and can be seen as a combination of institutions, actors and actions [2]. Looking at such a new type of combined judicandum responds to the observation that the sustainability relations are often governed by complex systems of mediation and are subject to uncertainty over the long-term (Section 2.2).

As this new type of combined judicandum is so vast, vague and complex, at the moment no single (individual or collective) actor could on their own change them and thus be a responsible claim addressee. This gives rise to three implications: Either (1) this means that adequate claim addressees need to be created, such as collective actors with sufficient power and knowledge to control these systems (see Section 4.1); or (2) the systems need to be changed and simplified so that they are subsequently controllable by less powerful and less knowledgeable claim addressees; or (3) one might need to acknowledge that some of these systems are principally not amenable to control and it therefore makes no sense to speak of them as judicanda.

\subsection{Informational Base}

Which informational base for the justice assessment is appropriate for a specific sustainability-fitting conception of justice depends on the claim contents defined in this conception, may differ between the sustainability relations and needs to take account of epistemological restrictions, as follows.

First, the appropriate informational base depends on the specification of claims (Section 4.2) within the specific conception of sustainability justice. For example, if one defines "individual security" or "basic well-being" as a claim of the claim holders, the informational base must be some measure or index for this claim content. For example, Page [35] discusses capabilities, welfare, and resources as alternative informational bases for an intergenerational claim to a certain level of well-being.

Second, the informational base should be universal in the sense that it should be applicable, at least, to all claim holders of equal moral standing within one of the sustainability relations described in Section 2.2. However, the informational base between different sustainability relations might need to be different. This is true even in cases of equal claims. For example, "well-being" might mean something different for "nature" (or entities in nature, such as certain animals) than for humans. In cases of unequal claims, it follows as well that unequal informational bases are required.

Third, one crucial epistemological feature of sustainability is the uncertainty or even ignorance one is facing within the sustainability context (Section 2.2). This uncertainty or ignorance may differ with regard to the judicandum and the sustainability relation one is looking at but is a general characteristic of the informational base of any sustainability-fitting conception of justice. Uncertainty about the future 
and about nature's functioning might lead to the ruling out of some informational bases for intergenerational justice and justice towards nature, as the information is just not available with reasonable certainty for this relation. For example, Howarth rules out utility as an informational base for intergenerational justice, because it "depends on an analyst's ability to accurately predict the future using models that fully integrate anticipated social, economic and environmental trends" [148] (p. 660). For every relation, one needs to ask: What is the best proxy or indicator available for the fulfilment (or breaching) of the claim(s) given the context?

Overall, the informational base to measure the fulfilment of claims may thus be different between the sustainability relations for several reasons: because the fulfilment of the same claim means something different for the different partners in the sustainability relations (e.g., "well-being" for a human or for an animal), because the claims ascribed to the partners are different (e.g., because they are assigned different moral standing or different interests, goods, or rights, $c f$. Section 4.2), or because only different information is available.

\subsection{Principles of Justice}

Which principles of justice are appropriate for sustainability-fitting conceptions of justice, regarding the obligations of claim addressees and the claims of the claim holders (and corresponding informational bases)?

Looking first at principles regarding obligations, one has to consider the difference between, and the asymmetry of, the sustainability relations (Section 2.2). For instance, the possibilities of communication and involvement are rather different with regard to other contemporaries, future generations, and nature. Also, each sustainability relation shows an asymmetry with regard to power and abilities. Current persons can impact the future, but not vice versa; and humans can impact nature in different ways than nature can impact humans; and contemporaries have very different means and possibilities to act and influence others. Therefore, one should not assume per se that the partners of the three relations (other contemporaries, future humans, and natural entities) have exactly the same duties or obligations [2]. Rather, to reflect the asymmetries and uncertainties of the sustainability context, one can argue that a particular claim addressee's obligations should be determined according to a principle of proportionality with regard to that claim addressee's power and knowledge (as expressed, e.g., in the capability and responsibility clauses of $[156,157]$ ), or even according to a principle of priority, stating that the most powerful or wealthy should have an obligation to act first and foremost, if not exclusively (e.g., [26]).

We are now turning to principles regarding claims (and corresponding informational bases). Referring to the limits that are a core characteristic of sustainability (Section 2.2), Hayward [59] (p. 10) points out: "As natural and finite beings in a natural and finite world, therefore, humans must heed this finitude, and not assume that distributive principles can be developed in abstraction from it." The limited possibility to satisfy claims in the sustainability context must therefore be taken into account in the formulation of principles already. The status and priority of different claims must be determined for the case that not all can be satisfied (see also Section 4.2). Depending on the specific understanding of the human being and nature, one can justify certain principles of priority (e.g., if claims are different in importance or urgency). Priority is a relative notion, aiming at fulfilling the 
most important or urgent claims first. For example, the Brundtland report emphasizes the "overriding priority" of the needs of the world's poor [61] (Chapter $2 \S 1$ ) (see also [83]). An alternative (or complementary) way is to use a principle of sufficiency, defining what is "enough" for a claim holder. Several authors have defended an absolute sufficientarian threshold for intergenerational justice (see e.g., [36,90,96,158]), defining a minimum level of some good to which every claim holder is entitled. For claims of nature or natural entities, a sufficientarian threshold might also be defined, but will probably contain a different set of minimum claims. Even for such conceptions of justice which assign equal moral standing to certain natural beings, e.g., certain animals, the set of claims will probably different, as these animals have different interests or a different "good" than humans and therefore different claims, according to most grounds of justice.

Such an absolute definition of claims can be understood as a minimal requirement of justice as part of a two-step conception of justice. When the sufficientarian threshold is attained, further requirements (maybe according to a different principle, such as equality or proportionality) may be added. A sufficientarian account, some argue, is better able to deal with uncertainty and indeterminacy than accounts based e.g., only on equality, as one does not need complete knowledge of outcomes and can focus on attaining minimal justice (see e.g., [35] with reference to Nussbaum's account of capabilities).

Principally, one has to take into account the possibility of defining different principles for different domains of application, based on different grounds of justice, and with respect to different communities of justice [76]. This results in multiple principles, applying to different, but embedded communities of justice. In the sustainability context, multiple principles might be necessary because of the encompassing scope implied in the sustainability concept, the different sustainability relations (with different grounds of justice associated), and the uncertainty related to them (Section 2.2). One should also consider the effect of the mediating systems characteristic of the sustainability context (Section 2.2), which may counteract simple distributive principles, and consider whether this needs to be taken into account in the formulation of the principles. The multiple principles could be cumulative, i.e., add up and complement each other. However, different grounds of justice may also lead to conflicting principles in the sustainability context, in which case any sustainability-fitting conception of justice needed to provide a way of handling such conflicts.

\subsection{Instruments of Justice}

What kind of instruments can be employed to fulfil the claims of currently living humans, of humans living in the future, and of "nature" or certain natural beings in the name of sustainability? How can these claims be fulfilled?

As instruments of justice are geared towards the fulfilment of claims by claim addressees, which instruments are appropriate of course depends on which claims and claim addressees are defined by the specific conception of sustainability justice (see Sections 4.1 and 4.2). There are a number of further general requirements on instruments of justice arising from the core characteristics of sustainability, as we will discuss in this Section. Furthermore, which instruments are seen as appropriate in the sustainability context crucially depends on basic ontological and epistemological assumptions (Section 2.1). Instruments need to be seen as effective to achieve the desired claim fulfilment (see, e.g., [159] on "levers of 
change"). Different framings of the problem at hand [160] will lead to different instruments that are proposed.

The encompassing temporal scope of the sustainability concept (Section 2.2) means that for intergenerational claims, one needs to design instruments of justice that have some durable effect so that they can serve future humans in the fulfilment of their claims. Classic conceptualizations refer to the continuance of certain types of capital or environmental resources (e.g., [148]). On can also construct a requirement to maintain a certain quality of the environment [37]. Ott [26] argues for an institutionalization of a concern for the future, e.g., through a special government branch that has the task to implement the critical natural capital rule, thereby ensuring a long-term commitment of the state to sustainability.

The encompassing spatial scale of the sustainability concept (Section 2.2), having implications for the type of claim holders, claims and claim addressees that arise globally among contemporaries, also needs to be considered in the design of instruments. While some intragenerational claims may well be satisfied with local instruments (e.g., basic needs satisfaction through local food generation), other global claims may only be satisfiable when taking into account and addressing the mediation of relationships through economic, scientific, and technological systems (as defined in Section 2.2).

The mediation of relationships thus has implications for global justice today, but also in the other sustainability relations. Instruments of sustainability justice have, at least, to take into account the effects of these systems, or even to directly address them, by considering a reform of these systems. For instance, instruments like Corporate Social Responsibility (CSR) and initiatives like the UN Global Compact, in combination with regulations, may contribute to a reform of the economic system. Different actors need to work together to make this reform possible, or new actors with a higher extent of power and abilities need to be introduced (see also Section 4.1). Another example is the reform of scientific systems, by movements such as sustainability science (e.g., [161]).

Different characteristics of sustainability hint to the importance of science and education as instruments of sustainability justice (see also the recommendations in [162]). Individual education and learning can give insights into the threefold relationality of the human being. This also links to conceiving of individual actors as claim addressees and also as judicanda (Sections 4.1 and 4.3). Science and education can furthermore foster technical and scientific knowledge required to tackle the challenges of sustainability and to understand how to continue the desired systems, process, entities or measures (Section 2.2). At the same time, the uncertainty and ignorance present in the sustainability context (Section 2.2) hint to the fact that no full understanding of their functioning may be reachable and that a proper system of generation, storage and transfer of knowledge is needed (see also [66]).

More generally, the ubiquitous uncertainty may require the reduction of complexity of certain systems, and the foregoing of technologies that could cause further uncertainties. It also means that in many cases, one cannot exactly know whether a certain instrument will suffice to satisfy certain claims of sustainability justice. Therefore, one may argue that a step-by-step approach which is resilient and error-friendly [163] is needed, so that it can handle failure in parts of the system without major consequences for the whole system.

The asymmetries present in the sustainability relations may be countered, at least partly, by procedural instruments of participation and representation. In the intragenerational realm, participation is an established instrument to balance out power differentials. It is prominently advocated in the 
sustainability context (as a classic example, see [80]). Representation in decisions is also advocated to address the asymmetries in the intergenerational relationships between humans and in the relationship towards nature: Organizations such as, for instance, the World Future Council or the World Wildlife Fund, claim to represent the interests or good of future humans and nature.

Different instruments may interact in their effects. An instrument which is geared to fulfil claims within one sustainability relation may have (positive or negative) effects for other relations as well. For example, conserving natural capital for members of future generations may have opportunity costs that are distributed very unevenly within the current generation (where most of the direct opportunity costs occur in agriculture, forestry, fishery, according to [26]). This must be taken into account in the design of instruments (e.g., by designing supplementary measures to distribute opportunity costs fairly, $c f$. [26]). As another example, instruments geared to fulfil intragenerational claims (e.g., to satisfy the basic needs of all current humans), may have positive or negative consequences on the environment, and therefore on claims within the relationship between humans and nature (see $[130,152]$ for different possible relationships - rivalry, facilitation (win-win), or independence - in attaining inter- and intragenerational justice, and [26] for a critical view on the "win-win" hypothesis between poverty reduction and environmental protection).

Finally, any instrument of justice, or at least all instruments of justice taken together, must respect the limits that are a core characteristic of sustainability (Section 2.2). Otherwise, their effect cannot be positively durable and therefore not truly sustainable.

\section{Conclusion and Outlook: Towards Sustainability Justice}

In this paper, we have argued that the normative dimension of sustainability can be captured in terms of justice. Based on the core characteristics of sustainability, we have discussed the shapes of sustainability-fitting justice conceptions along the lines of a general conceptual structure of justice.

In this Section, we sum up the requirements for any conception of sustainability justice (Section 5.1) and discuss how the requirements we identify for the specification of the justice elements in the sustainability context fit with specifications (and possible extensions) of established theories of justice (Section 5.2). Finally, we draw some conclusions for the conceptual debate, as well as for sustainability policy and sustainability research (Section 5.3).

\subsection{Sustainability Justice}

Sustainability justice refers to the synthesis — not merely the sum - of the justice claims in the three sustainability relations, referring to inter- and intragenerational justice between humans, and justice towards nature. The specification of conceptions of sustainability justice is contingent in a twofold way: First, the specification of the elements of justice should fit the concept of sustainability with its core characteristics and underlying ontological, epistemological and ethical assumptions; and second, the elements should be consistent with each other (for example, claims and informational base). Thus, the elements of a sustainability-fitting justice conception can and should not be specified at random, but should ideally be derived systematically from a conception of sustainability and be consistent with each other (and with consistent ontological, epistemological and ethical assumptions). 
Sustainability justice requires addressing the claims of currently living humans, humans of future generations, and, as applicable, nature in an integrated way. Any sustainability-fitting justice conception needs at least to consider these three groups of potential claim holders, and give reason for the inclusion or exclusion of members of these groups in the community of justice (see [12] for a similar argument, compare also [164] (p. 3)). If nature is not seen as a claim holder in its own right, sustainability justice "shrinks" to a synthesis of the justice claims within the inter- and intra-generational relations of humans. The claim holders' claims may be defined in different ways (e.g., in terms of a "decent life", "security" or in terms of being treated virtuously), depending on the ground of justice. Moreover, there are some general requirements for the specification of claims from the core characteristics of sustainability, e.g., the avoidance of risks (derived from the uncertainty prevalent in the sustainability context) and the provision under which justice can flourish and under which obligations to later generations can be fulfilled (derived from the asymmetry of the sustainability relations). A sufficientarian threshold of claims may be formulated as a minimum standard of sustainability justice. Such an approach based on the sufficiency principle arguably allows better to deal with uncertainty and indeterminacy. Alternatively (or complementarily), one may apply a principle of priority (e.g., for the needs of the world's poor). The informational base to measure the fulfilment of claims needs to be consistent with the claims formulated in the specific conception of sustainability justice, may differ between the sustainability relations and needs to take account of epistemological restrictions.

Claim addressees need to be actors fulfilling the preconditions of (negative and positive) responsibility: freedom, sufficient knowledge and power to act. Responsibility may be divided between different (individual and collective) actors, and between (present and future) generations: A dynamic perspective is needed, allowing for new claim addressees to be defined in the future. This in turn involves an obligation to sustain conditions in which these future claim addressees will be able to fulfil their obligations. Furthermore, the asymmetries of the sustainability relations imply that obligations should be determined according to the principles of proportionality and priority (where more ability to act implies more — or exclusive — obligations). Different grounds of justice may give rise to a plurality of principles both regarding obligations and regarding claims. These plural principles may complement each other, but may also lead to conflicting claims and obligations.

The judicanda of sustainability-fitting justice conceptions can in principle belong to all four established categories of judicanda: actors, actions, rules or states of affairs. As the sustainability relations are often mediated by complex economic, technological and scientific systems, these structures constitute further, and indeed very important, judicanda of sustainability justice. Coping with these systems in a sustainable manner might require their reform (as an instrument of justice), and also supposes the existence and definition of adequate claim addressees (such as collective actors). In general, the adequate instruments depend on the specification of claims and claim addressees by a specific conception of sustainability-fitting justice. We have discussed instruments on both individual and collective, and on both local and global levels.

\subsection{Established Theories of Justice and Sustainability}

The requirements for sustainability-fitting justice conceptions are a challenge for established theories of justice. Aspects such as future generations, nature, encompassing scope in time and space, 
uncertainty, and systemic mediation were not the main focus of traditional theories of justice. These aspects have been addressed only casually, if at all.

For instance, the extended definition of the community of justice, with the need to include the members of the current generation and some or all members of future generations as well as natural entities as claim holders, goes beyond many established theories of justice, as many philosophers defined the community of justice more narrowly in time and space. Particularly the extension to natural entities, e.g., sentient beings, is in contrast to many conceptions of justice that originally defined the community of justice by humans and operated on a strict distinction between humans and other beings, such as the conceptions of Kant [165,166] or Rawls [17]. However, some theories of justice, e.g., utilitarian based theories [42] or some versions of the environmental justice approach [167], allow the inclusion of non-human beings as claim holders. Moreover, one also needs to consider that relevant communities - the current generation, future generations, and natural entities - may be very amorphous in themselves, which poses further questions of justice within these communities.

Considering economic, technological and scientific systems (with their institutionalizations and fundamental patterns of thought and action, see Sections 2.2 and 4.4 and [2]) as judicanda also is a challenge to traditional theories of justice. Traditional political philosophy was focused on immediate interactions of individuals and on basic political and societal structures, referring mainly to the state. Jonas [62,63] referred to this traditional political philosophy as an ethics of the "here and now". Even Rawls' [17] approach, which particularly focused on social justice and the related societal and political arrangements, cannot fully capture the complex economic, technological and scientific systems that are a primary judicandum of sustainability justice.

Taking uncertainty seriously as a circumstance of sustainability also is a challenge to many justice theories, especially consequentialistic approaches which assess the outcomes of certain judicanda (e.g., one's actions) as just or unjust. In particular, when outcomes extend far in time or space, it may become rather difficult to assess them with reasonable certainty

As sustainability is a global task, a further challenge is to find a "common language" and link ethical analyses based on predominantly "Western" thought to other schools of thought, in order to give sustainability justice an intercultural and global footing.

Therefore, any effort to apply established theories of justice to sustainability needs to be aware of potential limits and frictions. Established theories of justice need to be substantially modified with regard to the specific characteristics of sustainability and the resulting general requirements for sustainability-fitting justice conceptions outlined in Section 4.

\subsection{Concluding Remarks and Outlook}

We have demonstrated that sustainability, if it is to be captured in terms of justice, implies specific requirements for any adequate conception of sustainability justice. In particular, a sustainability-fitting justice conception needs to be consistent with the core characteristics of sustainability and its underlying assumptions. Existing theories of justice do not meet all the requirements. While there have been some modifications of traditional theories to address sustainability ([2,26,35-37,131], among others), more research is needed to develop conceptions of sustainability justice that treat the claims within all three sustainability relations (that is, in the relations of current persons with contemporaries, 
future humans and nature) in an integrated way, and take account of the core characteristics of sustainability and their underlying assumptions.

As we have pointed out (Section 2), sustainability is an integrative concept and therefore, sustainability justice should aim to integrate different claims arising within different sustainability relations and aim to achieve them simultaneously. This is particularly challenging in the non-ideal circumstances of sustainability, especially the limits that are characteristic of the sustainability context (Section 2.2). These limits may lead to problems of feasibility on the "production side" and therefore require decisions on how to handle such conflicts on the "value side" (see also Section 4.2). One may assign priority or greater weight to one type of claim (e.g., the needs of the world's poor [61] (Chapter $2 \S 1$ )). One may define a certain minimum threshold for each type of claim and treat such claims (and the corresponding obligations) as mutual constraints (as [26] considers for inter- and intragenerational obligations; compare also [168]). One may assign prima facie equal rank to the claims within different relations ( $c f$. [152]). One may decide on the relative importance and urgency of claims case-by-case depending on the specific grounds of justice relevant in the context (as hinted at in Section 4.2), or use procedural rules to resolve conflicts of claims ( $c f$. [169]). Advancement in these questions is an important challenge for the development of a sustainability-fitting justice conception countering the danger of "overburdening" [26] of the concept while living up to its integrative nature.

Our approach of interpreting sustainability as justice at the general conceptual level helps to systematically understand the option space and different possibilities for specifications of the normative dimension of sustainability, depending on the set of underlying basic ontological, epistemological and ethical assumptions. Our discussion in this paper is a rough sketch of all the possibilities to specify the conceptual elements of sustainability justice. All specifications of the conceptual elements of sustainability justice - both the ones we discuss in Section 4 and those that others may add to the debate - depend on multiple, potentially contested underlying assumptions which need to be made explicit and discussed. In this regard, the paper constitutes a starting point for further debate and research. Many of the difficulties that sustainability poses to ethics must remain unsolved at this point and may be seen as challenges for further research.

Sustainability research needs to systematically incorporate the normative dimension of sustainability and be consistent with the basic understanding of the world it is based on. Many of the approaches put forward in the literature, however, are not explicit about their underlying ethical, ontological and epistemological assumptions [71]. In particular, the normative dimension of sustainability should not be treated as an add-on, but should be an integral part of sustainability research (see also [170]). A purely descriptive enquiry into the systems, processes, or entities to be continued (see Section 2.2) alone cannot give guidance on how to act in a sustainable manner. This goes across and beyond different forms of knowledge that are needed to tackle sustainability problems, including systems knowledge, target knowledge and transformation knowledge [44,171] (for a critical note see [172]). Underlying ethical, ontological and epistemological assumptions need to be scrutinized for all these forms of knowledge, and normative decisions need to be made explicit, including in scientific problem choice, delineation of the system to be studied and assessments and their underlying (often tacit) values.

In view of policy-making, the specification of claim holders and claim addressees, claims and obligations, informational base and principles, judicanda and instruments allows clarifying goals and 
responsibilities for sustainability policies. This is especially important in the face of limited feasibility, where a well-specified conception of sustainability justice can give guidance to handle trade-offs between different claims and goals.

To sum up, the systematic and general conceptual framework proposed here contributes to the conceptual clarification in the debate on justice and sustainability. It can serve the future debate about justice in the context of sustainability, may give guidance to sustainability policy and may motivate and guide the future direction of research for sustainability.

\section{Acknowledgments}

We thank Marius Christen, Gertrude Hirsch Hadorn, Bernd Klauer, participants at the 2013 conference of the International Association for Environmental Philosophy and participants at the 2013 conference of the European Society for Ecological Economics, as well as two anonymous reviewers of this journal for helpful comments. Financial support from the German Federal Ministry of Education and Research (BMBF) under grant 01UN1011A is gratefully acknowledged.

\section{Author Contributions}

Christian U. Becker, Klara Helene Stumpf, Stefan Baumgärtner, Stefanie Sievers-Glotzbach developed the idea, motivation and question of the paper and contributed to the discussion. Klara Helene Stumpf, Christian U. Becker, Stefan Baumgärtner provided a conceptual clarification. Klara Helene Stumpf provided the research design, most of the literature review, and writing in all sections. Christian U. Becker provided writing in parts of Sections 2 and 4.

\section{Conflicts of Interest}

The authors declare no conflict of interest. The funding sponsors had no role in the design of the study; in the collection, analyses or interpretation of data; in the writing of the manuscript, in in the decision to publish the results.

\section{References}

1. Hadorn, G.H.; Bradley, D.; Pohl, C.; Rist, S.; Wiesmann, U. Implications of transdisciplinarity for sustainability research. Ecol. Econ. 2006, 60, 119-128.

2. Becker, C. Sustainability Ethics and Sustainability Research; Springer: Dordrecht, Germany, 2012.

3. Mill, J.S. Utilitarianism; Crisp, R., Ed.; Oxford University Press: Oxford, UK, 1998.

4. Gethmann, C.F.; Mittelstrass, J. Langzeitverantwortung. Ethik, Technik, Ökologie; Gethmann, C.F., Mittelstrass, J., Eds.; Wissenschaftliche Buchgesellschaft: Darmstadt, Germany, 2008. (In German)

5. Baumgärtner, S.; Klauer, B.; Petersen, T.; Quaas, M.F.; Schiller; J.; Stumpf, K.H. Sustainability under Uncertainty as Responsibility. In Proceedings of the Conference of the International Society for Ecological Economics (ISEE), Oldenburg/Bremen, Germany, 22-25 August 2010.

6. Baumgärtner, S.; Petersen, T.; Schiller, J. Bringing Norms into Action: The Concept of Responsibility. 2014, unpublished work. 
7. Schefczyk, M. Verantwortung für Historisches Unrecht: Eine Philosophische Untersuchung; De Gruyter: Berlin, Germany, 2012. (In German)

8. Newton, L.H. Ethics and Sustainability. Sustainable Development and the Moral Life; Prentice Hall: Upper Saddle River, NJ, USA, 2003.

9. Raymond, L. Private Rights in Public Resources: Equity and Property Allocation in Market-Based Environmental Policy; Resources for the Future: Washington, DC, USA, 2003.

10. Barry, B. Sustainability and intergenerational justice. Theoria 1997, 45, 43-65.

11. Lélé, S.M. Sustainable development: A critical review. World Dev. 1991, 19, 607-621.

12. Dobson, A. Justice and the Environment. Conceptions of Environmental Sustainability and Theories of Distributive Justice; Oxford University Press: Oxford, UK, 1998.

13. Jacobs, M. Sustainable development as a contested concept. In Fairness and Futurity. Essays on Environmental Sustainability and Social Justice; Dobson, A., Ed.; Oxford University Press: Oxford, UK, 1999; pp. 21-45.

14. Connelly, S. Mapping sustainable development as a contested concept. Local Environ. 2007, 12, 259-278.

15. Zaccai, E. Over two decades in pursuit of sustainable development: Influence, transformations, limits. Environ. Dev. 2012, 1, 79-90.

16. Gallie, W.B. Essentially contested concepts. Proc. Aristot. Soc. 1956, 56, 167-198.

17. Rawls, J. A Theory of Justice; The Belknap Press of Harvard University Press: Cambridge, MA, USA, 1971.

18. Burger, P.; Christen, M. Towards a capability approach of sustainability. J. Clean. Product. 2011, 19, 787-795.

19. Christen, M.; Schmidt, S. A formal framework for conceptions of sustainability-A theoretical contribution to the discourse in sustainable development. Sustain. Dev. 2012, 20, 400-410.

20. Waas, T.; Hugé, J.; Verbruggen, A.; Wright, T. Sustainable development: A bird's eye view. Sustainability 2011, 3, 1637-1661.

21. Dobson, A. Fairness and Futurity. Essays on Environmental Sustainability and Social Justice; Dobson, A., Ed.; Oxford University Press: Oxford, UK, 1999.

22. Daly, H. Economics, Ecology, Ethics. Essays toward a Steady-State Economy; Daly, H., Ed; W.H. Freeman: San Francisco, CA, USA, 1980.

23. Ott, K.; Thapa, P.; Greifwald's Environmental Ethics; Ott, K., Thapa, P., Eds.; Steinbeckerverlag Rose: Greifswald, Germany, 2003.

24. Agyeman, J.; Bullard, R.D.; Evans, B. Just Sustainabilities. Development in an Unequal World; Agyeman, J., Bullard, R.D., Evans, B., Eds.; Earthscan: London, UK, 2003.

25. Norton, B.G. Sustainability. A Philosophy of Adaptive Ecosystem Management; University Press: Chicago, IL, USA, 2005.

26. Ott, K. Institutionalizing strong sustainability: A Rawlsian perspective. Sustainability 2014, 6, 894-912.

27. Sen, A.K. On Economic Inequality; Oxford University Press: Oxford, UK, 1973.

28. Leist, A. Ökologische Gerechtigkeit als bessere Nachhaltigkeit. Aus Politik Zeitgesch. 2007, 24, $3-10$. 
29. Sikora, R.I.; Barry, B. Obligations to Future Generations; Sikora, R.I., Barry, B., Eds.; Temple University Press: Philadelphia, PA, USA, 1978.

30. Partridge, E. Responsibilities to Future Generations; Partridge, E., Ed.; Prometheus: Buffalo, NY, USA, 1981.

31. Partridge, E. Just provision for the future. Intergener. Justice Rev. 2008, 1, 4-8.

32. Parfit, D. Reasons and Persons; Oxford University Press: Oxford, UK, 1984.

33. Unnerstall, H. Rechte Zukünftiger Generationen; Königshausen \& Neumann: Würzburg, Germany, 1999.

34. Tremmel, J.C. Handbook of Intergenerational Justice; Tremmel, J.C., Ed.; Edward Elgar: Cheltenham, UK, 2006.

35. Page, E.A. Intergenerational justice of what: Welfare, resources or capabilities? Environ. Politics 2007, 16, 453-469.

36. Page, E.A. Justice between generations: Investigating a sufficientarian approach. J. Glob. Ethics 2007, 3, 3-20.

37. Habib, A. Sharing the earth: Sustainability and the currency of inter-generational environmental justice. Environ. Values 2013, 22, 751-764.

38. Dower, N. Global economy, justice and sustainability. Ethic. Theory Moral Pract. 2004, 7, 399-415.

39. Stone, C. Should Trees Have Standing? Toward Legal Rights for Natural Objects; William Kaufmann: Los Altos, CA, USA, 1974.

40. Stone, C. Should Trees Have Standing? Law, Morality and the Environment, 3rd ed.; Oxford University Press: Oxford, UK, 2010.

41. Regan, T. The Case for Animal Rights; University of California Press: Berkeley, CA, USA, 1983.

42. Singer, P. Animal Liberation, 2nd ed.; New York Review Book: New York, NY, USA, 1990.

43. Staples, W.; Cafaro, P. For a species right to exist. In Life on the Brink; Cafaro, P., Crist, E., Eds.; University of Georgia Press: Athens, GA, USA, 2012; pp. 283-300.

44. Wuelser, G.; Pohl, C.; Hirsch Hadorn, G. Structuring complexity for tailoring research contributions to sustainable development: A framework. Sustain. Sci. 2012, 7, 81-93.

45. Mitcham, C. The concept of sustainable development: Its origins and ambivalence. Technol. Soc. 1995, 17, 311-326.

46. Dobson, A. Environmental sustainabilities: An analysis and a typology. Environ. Politics 1996, 5, 401-428.

47. Klauer, B. Defining and achieving sustainable development. Int. J. Sustain. Dev. World Ecol. 1999, 6, 114-121.

48. Pezzey, J.; Toman, M.A. The Economics of Sustainability: A Review of Journal Articles. 2002. Available online: http://www.rff.org/RFF/Documents/RFF-DP-02-03.pdf (accessed on 5 March 2015).

49. Pezzey, J.; Toman, M.A. Progress and problems in the economics of sustainability. In International Yearbook of Environmental and Resource Economics 2002/2003; Tietenberg, T., Folmer, H., Eds.; Edward Elgar: Cheltenham, UK, 2002; pp. 165-232.

50. Williams, C.C.; Millington, A.C. The diverse and contested meanings of sustainable development. Geogr. J. 2004, 170, 99-104. 
51. Hopwood, B.; Mellor, M.; O’Brien, G. Sustainable development: Mapping different approaches. Sustain. Dev. 2005, 13, 38-52.

52. Kuhlman, T.; Farrington, J. What is sustainability? Sustainability 2010, 2, 3436-3448.

53. Williams, B. Ethics and the Limits of Philosophy; Fontana Press: London, UK, 1985.

54. Putnam, H. The Collapse of the Fact/Value Dichotomy and Other Essays; Harvard University Press: Cambridge, MA, USA, 2002.

55. Roberts, D. Thick concepts. Philos. Compass 2013, 8, 677-688.

56. Robinson, J. Squaring the circle? Some thoughts on the idea of sustainable development. Ecol. Econ. 2004, 48, 369-384.

57. Baumgärtner, S.; Becker, C.; Frank, K.; Müller, B.; Quaas, M.F. Relating the philosophy and practice of ecological economics. The role of concepts, models, and case studies in inter- and transdisciplinary sustainability research. Ecol. Econ. 2008, 67, 384-393.

58. Muraca, B. The map of moral significance: A new axiological matrix for environmental ethics. Environ. Values 2011, 20, 375-396.

59. Hayward, T. Political Theory and Ecological Values; St. Martin's Press: New York, NY, USA, 1998.

60. Pelletier, N. Environmental sustainability as the first principle of distributive justice: Towards an ecological communitarian normative foundation for ecological economics. Ecol. Econ. 2010, 69, 1887-1894.

61. World Commission on Environment and Development (WCED). Our Common Future; Oxford University Press: New York, NY, USA, 1987.

62. Jonas, H. Philosophical Essays: From Ancient Creed to Technological Man; Prentice Hall: Englewood Cliffs, NJ, USA, 1974.

63. Jonas, H. The Imperative of Responsibility. In Search of an Ethics for the Technological Age; Chicago University Press: Chicago, IL, USA, 1984.

64. March, J.G.; Olsen; J.P. The institutional dynamics of international political orders. Int. Organ. 1998, 52, 943-969.

65. Fergus, A.H.T.; Rowney; J.I.A. Sustainable development: Lost meaning and opportunity? J. Bus. Ethics 2005, 60, 17-27.

66. Norgaard, R.B. Sustainable development: A co-evolutionary view. Futures 1988, 20, 606-620.

67. Steup, M. Epistemology. In The Stanford Encyclopedia of Philosophy, Spring 2014 ed.; Zalta, E.N., Ed.; Stanford University: Stanford, CA, USA, 2014. Available online: http://plato.stanford.edu/ archives/spr2014/entries/epistemology (accessed on 5 March 2015).

68. Chakravartty, A. Scientific Realism. In The Stanford Encyclopedia of Philosophy, Summer 2013 ed.; Zalta, E.N., Ed.; Stanford University: Stanford, CA, USA, 2013. Available online: http://plato.stanford.edu/archives/sum2013/entries/scientific-realism (accessed on 5 March 2015).

69. Funtowicz, S.O.; Ravetz, J.R. The worth of a songbird: Ecological economics as a post-normal science. Ecol. Econ. 1994, 10, 197-207.

70. Funtowicz, S.O.; Ravetz, J.R. Science for the Post-Normal Age. Futures 1993, 25, 739-755.

71. Spash, C.L. New foundations for ecological economics. Ecol. Econ. 2012, 77, 36-47.

72. Faber, M.; Manstetten R.; Proops, J. Humankind and the environment: An anatomy of surprise and ignorance. Environ. Values 1992, 1, 217-242. 
73. Potthast, T. Wo sich Biologie, Ethik und Naturphilosophie treffen (müssen). Epistemologische und moralphilosophische Aspekte der Umweltethik. In Spektrum der Umweltethik; Ott, K., Gorke, M., Eds.; Metropolis: Marburg, Germany, 2000; pp. 101-146. (In German)

74. Campbell, R. Moral epistemology. In The Stanford Encyclopedia of Philosophy, Spring 2014 ed; Zalta, E.N., Ed.; Stanford University: Stanford, CA, USA, 2014. Available online: http://plato.stanford.edu/archives/spr2014/entries/moral-epistemology/ (accessed on 5 March 2015).

75. Feinberg, J. The rights of animals and unborn generations. In Responsibilities to Future Generations; Partridge, E., Ed.; Prometheus: Buffalo, NY, USA, 1981; pp. 139-150.

76. Risse, M. On Global Justice; Princeton University Press: Princeton, NJ, USA, 2012.

77. Grober, U. Sustainability: A Cultural History; Green Books: Devon, UK, 2012.

78. Neumayer, E. Weak versus Strong Sustainability. Exploring the Limits of Two Opposing Paradigms, 3rd ed.; Edward Elgar: Cheltenham, UK, 2010.

79. Kates, R.W.; Parris, T.M.; Leiserowitz, A.A. What is sustainable development? Goals, indicators, values, and practice. Environment 2005, 47, 8-21.

80. United Nations (UN). Agenda 21; United Nations: New York, NY, USA, 1992.

81. United Nations (UN). United Nations Millennium Declaration; Resolution 55/2, Adopted by the General Assembly; United Nations: New York, NY, USA, 2000.

82. United Nations (UN). The Future We Want; Resolution 66/288, adopted by the General Assembly; United Nations: New York, NY, USA, 2012.

83. Langhelle, O. Sustainable development: Exploring the ethics of Our Common Future. Int. Political Sci. Rev. 1999, 20, 129-149.

84. Tilbury, D.; Stevenson, R.B.; Fien, J.; Schreuder, D. Education and Sustainability. Responding to the Global Challenge; Tilbury, D., Stevenson, R.B., Fien, J., Schreuder, D., Eds.; Commission on Education and Communication, IUCN: Gland, Switzerland; Cambridge, UK, 2002.

85. National Research Council. Our Common Journey. A Transition toward Sustainability; National Academy Press: Washington, DC, USA, 1999.

86. United Nations (UN). Report of the World Summit on Sustainable Development; United Nations: New York, NY, USA, 2002.

87. Ng, Y.-K. Sustainable development: A problem of environmental disruption now instead of intertemporal ethics. Sustain. Dev. 2004, 12, 150-160.

88. Barbier, E.B.; Burgess, J.C.; Folke, C. Paradise Lost? The Ecological Economics of Biodiversity; Earthscan: London, UK, 1994.

89. Earth Charter Commission. The Earth Charter. Available online: http://www.earthcharterinaction.org/ invent/images/uploads/echarter_english.pdf (accessed on 5 March 2015).

90. Ott, K.; Döring, R. Theorie und Praxis Starker Nachhaltigkeit, 2nd ed.; Metropolis: Marburg, Germany, 2008. (In German)

91. Benyus, J. Biomimicry. Innovation Inspired by Nature; Harper Perenniel: London, UK, 2002.

92. Ayres, R.U.; Ayres, L.U. Handbook of Industrial Ecology; Ayres, R.U., Ayres, L.U., Eds.; Edward Elgar: Cheltenham, UK, 2001.

93. Isenmann, R. Industrial ecology: Shedding more light on its perspective of understanding nature as model. Sustain. Dev. 2003, 11, 143-158. 
94. Costanza, R. Ecological Economics. The Science and Management of Sustainability; Columbia University Press: New York, NY, USA, 1991.

95. Bacon, F. The New Organon; Taggard \& Thompson: Boston, MA, USA, 1863; Translated by Spedding, J., Ellis, R.L., Heath, D.D.

96. Meyer, L. Intergenerational justice. In The Stanford Encyclopedia of Philosophy, Spring 2010 ed.; Zalta, E.N., Ed.; Stanford University: Stanford, CA, USA, 2010. Available online: http://plato.stanford.edu/archives/spr2010/entries/justice-intergenerational/ (accessed on 5 March 2015).

97. Gardiner, S.M. A Perfect Moral Storm: The Ethical Tragedy of Climate Change; Oxford University Press: New York, NY, USA, 2011.

98. Baumgärtner, S. Temporal and thermodynamic irreversibility in production theory. Econ. Theory 2005, 26, 725-728.

99. Young, I.M. Responsibility for Justice; Oxford University Press: Oxford, UK, 2011.

100. Millennium Ecosystem Assessment (MEA). Ecosystems and Human Well-Being. A Framework for Assessment; Island Press: Washington, DC, USA, 2003.

101. United Nations Environment Programme (UNEP). Global Environment Outlook 5. Environment for the Future We Want; UNEP: Nairobi, Kenya, 2012.

102. Intergovernmental Panel on Climate Change (IPCC). Climate Change 2013: The Physical Science Basis. Working Groups I Contribution to the Fifth Assessment Report of the Intergovernmental Panel on Climate Change; Cambridge University Press: Cambridge, UK, 2013.

103. Rockström, J.; Steffen, W.; Noone, K.; Persson, Å.; Chapin, F.S., III; Lambin, E.; Lenton, T.M.; Scheffer, M.; Folke, C.; Schellnhuber, J.H.; et al. Planetary boundaries: Exploring the safe operating space for humanity. Nature 2009, 461, 472-475.

104. Baumgärtner, S.; Becker, C.; Faber, M.; Manstetten, R. Relative and absolute scarcity of nature. Assessing the roles of economics and ecology for biodiversity conservation. Ecol. Econ. 2006, 59, 487-498.

105. Boulding, K.E. The economics of the coming spaceship Earth. In Environmental Quality in a Growing Economy; Jarrett, H., Ed.; Johns Hopkins University Press: Baltimore, MD, USA, 1966; pp. 3-14.

106. Georgescu-Roegen, N. The Entropy Law and the Economic Process; Harvard University Press: Cambridge, MA, USA, 1971.

107. Ayres, R.U. Resources, Environment and Economics. Applications of the Materials/Energy Balance Principle; Wiley: New York, NY, USA, 1978.

108. Daly, H.E. Toward a Steady-State Economy; W.H. Freeman: San Francisco, CA, USA, 1973.

109. Daly, H.E. Steady State Economics. The Economics of Biophysical Equilibrium and Moral Growth, 2nd ed.; W.H. Freeman: San Francisco, CA, USA, 1991.

110. Baumgärtner, S. Natural Science Constraints in Environmental and Resource Economics: Method and Problem. Available online: http://www.ub.uni-heidelberg.de/archiv/6593 (accessed on 5 March 2015).

111. Krysiak, F.C. Entropy, limits to growth, and the prospects for weak sustainability. Ecol. Econ. 2006, 58, 182-191. 
112. Ciriacy-Wantrup, S.V. Resource Conservation. Economics and Policies; University of California Press: Berkeley, CA, USA, 1952.

113. Bishop, R.C. Endangered species and uncertainty. The economics of a safe minimum standard. Am. J. Agric. Econ. 1978, 60, 10-18.

114. Krysiak, F.C. Sustainability and its relation to efficiency under uncertainty. Econ. Theory 2009, 41, 297-315.

115. Vare, P.; Scott, W. Learning for a change: Exploring the relationship between education and sustainable development. J. Educ. Sustain. Dev. 2007, 1, 191-198.

116. Barth, M.; Michelsen, G. Learning for change: An educational contribution to sustainability science. Sustain. Sci. 2013, 8, 103-119.

117. Sandin, P. Better Safe than Sorry: Applying Philosophical Methods to the Debate on Risk and the Precautionary Principle; Theses in Risk and Safety from the Division of Philosophy at the Royal Institute of Technology, 5; Infrastruktur: Stockholm, Sweden, 2004. Available online: http://urn.kb.se/resolve?urn=urn:nbn:se:kth:diva-90 (accessed on 5 March 2015).

118. Gosepath, S. Gerechtigkeit. In Lexikon Politik. Hundert Grundbegriffe; Fuchs, D., Roller, E., Eds.; Reclam: Stuttgart, Germany, 2007; pp. 82-85. (In German)

119. Stumpf, K.H.; Becker, C.U.; Baumgärtner, S. The conceptual structure of justice. Available online: http://ssrn.com/abstract=2572999 (accessed on 5 March 2015).

120. Ott, K. The spectrum of environmental values. In Greifswald's Environmental Ethics; Ott, K., Thapa, P., Eds.; Steinbeckerverlag Rose: Greifswald, Germany, 2003; pp. 31-40.

121. Baumgärtner, S.; Faber, M.M.; Schiller, J. Joint Production and Responsibility in Ecological Economics: On the Foundations of Environmental Policy; Edward Elgar: Northampton, UK, 2006.

122. Pogge, T.W. Justice. In Encyclopedia of Philosophy; Borchert, D.M., Ed.; Macmillan: Detroit, MI, USA, 2006; pp. 862-870.

123. Sen, A.K. Equality of What? The Tanner Lecture on Human Values; Cambridge University Press: Cambridge, UK, 1979; pp. 197-220.

124. Young, H.P. Equity in Theory and Practice; Princeton University Press: Princeton, NJ, USA, 1994.

125. Frankfurt, H.G. Equality as a moral ideal. Ethics 1987, 98, 21-43.

126. Krebs, A. Warum Gerechtigkeit nicht als Gleichheit zu begreifen ist. Deutsche Z. Philos. 2003, 51, 235-253.

127. Anand, S.; Sen, A.K. Human development and economic sustainability. World Dev. 2000, 28, 2029-2049.

128. Pogge, T.W. World Poverty and Human Rights: Cosmopolitan Responsibilities and Reforms, 2nd ed.; Polity Press: Cambridge, UK, 2008.

129. Aristotle. Nicomachean Ethics; Cambridge University Press: New York, NY, USA, 2000. translated by Crisp, R.

130. Glotzbach, S.; Baumgärtner, S. The relationship between intragenerational and intergenerational ecological justice. Environ. Values 2012, 21, 331-355.

131. Sievers-Glotzbach, S. Ecosystem services and distributive justice. Considering access rights to ecosystem services in theories of distributive justice. Ethics Policy Environ. 2013, 16, 162-176. 
132. Ott, K. Basic topics of future ethics. In Greifswald's Environmental Ethics; Ott, K., Thapa, P., Eds.; Steinbeckerverlag Rose: Greifswald, Germany, 2003; pp. 41-50.

133. Beckerman, W. The impossibility of a theory of intergenerational justice. In Handbook of Intergenerational Justice; Tremmel, J.C., Ed.; Edward Elgar Publishing: Cheltenham, UK, 2006; pp. 53-71.

134. Holland, A. The use and abuse of ecological concepts in environmental ethics. Biodivers. Conserv. 1995, 4, 812-826.

135. Gosseries, A. Historical emissions and free-riding. Ethical Perspect. 2004, 11, 38-62.

136. Baatz, C. Responsibility for the past? Some thoughts on compensating those vulnerable to climate change in developing countries. Ethics Policy Environ. 2013, 16, 94-110.

137. Ringius, L.; Torvanger, A.; Underdal, A. Burden sharing and fairness principles in international climate policy. Int. Environ. Agreem. 2002, 2, 1-22.

138. Dellink, R.; den Elzen, M.; Aiking, H.; Bergsma, E.; Berkhout, F.; Dekker, T.; Gupta, J. Sharing the burden of financing adaptation to climate change. Glob. Environ. Chang. 2009, 19, 411-421.

139. Intergovernmental Panel on Climate Change (IPCC). Climate Change: The IPCC Scientific Assessment; Cambridge University Press: Cambridge, UK, 1990.

140. Karnein, A. Putting Fairness in Its Place: Why There is a Duty to Take up the Slack. In Proceedings of the Workshop "Global Environmental Justice", University of Bremen, Bremen, Germany, 26 April 2013.

141. Blake, M.; Smith; P.T. International distributive justice. In The Stanford Encyclopedia of Philosophy, Winter 2013 ed.; Zalta, E.N., Ed.; Stanford University: Stanford, CA, USA, 2013. Available online: http://plato.stanford.edu/archives/win2013/entries/international-justice (accessed on 5 March 2015).

142. Schlosberg, D. Reconceiving environmental justice: Global movements and political theories. Environ. Politics 2004, 13, 517-540.

143. Becker, C.; Ewringmann, D.; Faber, M.; Petersen; T.; Zahrnt, A. Endangering the natural basis of life is unjust. On the status and future of the sustainability discourse. Ethics Policy Environ. 2015, 18, 60-67.

144. Commission on Human Security (CHS). Human Security Now; Commission on Human Security: New York, NY, USA, 2003.

145. Gasper, D. Securing humanity—Situating "human security" as concept and discourse. J. Hum. Dev. 2005, 6, 221-245.

146. Nussbaum, M.C. Women and Human Development. The Capabilities Approach; Cambridge University Press: Cambridge, UK, 2000.

147. Robeyns, I. The capability approach: A theoretical survey. J. Hum. Dev. 2005, 6, 93-117.

148. Howarth, R.B. Towards an operational sustainability criterion. Ecol. Econ. 2007, 63, 656-663.

149. Schmidtz, D. Respect for everything. Ethics Policy Environ. 2011, 14, 127-138.

150. Rodman, J. The liberation of nature? Inquiry 1977, 20, 83-145.

151. Jax, K.; Barton, D.N.; Chan, K.M.; de Groot, R.; Doyle, U.; Eser, U.; Görg, C.; Gómez-Baggethun, E.; Griewald, Y.; Haber, W.; et al. Ecosystem services and ethics. Ecol. Econ. 2013, 93, 260-268. 
152. Baumgärtner, S.; Glotzbach, S.; Hoberg, N.; Quaas, M.F.; Stumpf, K.H. Economic analysis of trade-offs between justices. Intergener. Justice Rev. 2012, 1, 4-9.

153. Le Grand, J. Equity versus efficiency: The elusive trade-off. Ethics Int. Affairs 1990, 100, 554-568.

154. DeGrazia, D. Taking Animals Seriously. Mental Life and Moral Status; Cambridge University Press: Cambridge, UK, 2001.

155. Goodin, R.E. Protecting the Vulnerable. A Reanalysis of our Social Responsibilities; University of Chicago Press: Chicago, IL, USA, 1985.

156. United Nations (UN). Convention on Biological Diversity; United Nations: New York, NY, USA, 1992.

157. United Nations (UN). United Nations Framework Convention on Climate Change; United Nations: New York, NY, USA, 1992.

158. Beckerman, W. Sustainable development and our obligations to future generations. In Fairness and Futurity. Essays on Environmental Sustainability and Social Justice; Dobson, A., Ed.; Oxford University Press: Oxford, UK, 1999; pp. 71-92.

159. Parris, T.M.; Kates, R.W. Characterizing a sustainability transition: Goals, targets, trends, and driving forces. Proc. Natl. Acad. Sci. USA 2003, 100, 8068-8073.

160. Martin, A. Global environmental in/justice, in practice: Introduction. Geogr. J. 2013, 179, 98-104.

161. Kates, R.; Clark, W.C.; Corell, R.; Hall, J.M.; Jaeger, C.C.; Lowe, I.; McCarthy, J.J.; Schellnhuber, H.J.; Bolin, B.; Dickson, N.M.; et al. Sustainability science. Science 2001, 292, 641-642.

162. Wissenschaftlicher Beirat der Bundesregierung Globale Umweltveränderungen (WBGU). Welt im Wandel: Gesellschaftsvertrag für eine Große Transformation, 2nd ed.; WBGU: Berlin, Germany, 2011.

163. Von Weizsäcker, E.U. Error friendly technologies. Bull. Sci. Technol. Soc. 1984, 4, 337-339.

164. Agyeman, J.; Bullard, R.D.; Evans, B. Joined-up thinking: Bringing together sustainability, environmental justice and equity. In Just Sustainabilities. Development in an Unequal World; Agyeman, J., Bullard, R.D., Evans, B., Eds.; Earthscan: London, UK, 2003; pp. 1-16.

165. Kant, I. Groundwork of the Metaphysics of Morals; Gregor, M., Ed. Cambridge University Press: Cambridge, UK, 1998; translated by Gregor, M.

166. Kant, I. Critique of Practical Reason; Gregor, M., Ed. Cambridge University Press: Cambridge, UK, 1997; translated by Gregor, M.

167. Schlosberg, D. Defining Environmental Justice. Theories, Movements, and Nature; Oxford University Press: New York, NY, USA, 2007.

168. Callahan, D. What obligations do we have to future generations? In Responsibilities to Future Generations; Partridge, E., Ed.; Prometheus: Buffalo, NY, USA, 1981; pp. 73-85.

169. Taylor, P. Respect for Nature. A Theory of Environmental Ethics; Princeton University Press: Princeton, NJ, USA, 1986.

170. Vucetich, J.A.; Nelson, M.P. Sustainability: Virtuous or vulgar? BioScience 2010, 60, 539-544.

171. ProClim. Research on Sustainability and Global Change-Visions in Science Policy by Swiss Researchers; ProClim: Bern, Switzerland, 1997. Available online: http://proclimweb.scnat.ch/ portal/ressources/1122.pdf (accessed on 5 March 2015). 
172. Burger, P.; Kamber, R. Cognitive integration in transdisciplinary science: Knowledge as a key notion. Issues Integr. Stud. 2003, 21, 43-73.

(C) 2015 by the authors; licensee MDPI, Basel, Switzerland. This article is an open access article distributed under the terms and conditions of the Creative Commons Attribution license (http://creativecommons.org/licenses/by/4.0/). 